\title{
Corporate Taxation, Corporate Power, and Corporate Harm
}

\author{
KEVIN FARNSWORTH and GARY FOOKS \\ Kevin Farnsworth is Senior Lecturer in International Social Policy, \\ University of York; Gary Fooks is Senior Lecturer in Sociology and Public Policy, \\ Aston University
}

\begin{abstract}
Globalisation has increased corporate tax competition amongst states and facilitated widespread corporate tax avoidance. Some of the largest businesses now pay little or no tax: in some cases with the active assistance of governments. This article examines contemporary corporation tax policies, outlines some of the key methods corporations use to minimise their tax liabilities, explores the interdependencies between the demand for reduced tax liabilities and the professional infrastructure of tax planning and avoidance, and examines how the contemporary political economy of corporate taxation enhances the bargaining power of transnational corporations in the implementation of tax policy.
\end{abstract}

Keywords: corporate taxation; corporate power; tax avoidance; corporate harm

Over the past 30 years, transnational corporations (TNCs) have lobbied successfully for reductions in corporation taxes and increases in various tax concessions and benefits. On top of this, TNCs routinely engage in tax avoidance schemes that result in actual tax rates far lower than headline rates. According to the UK National Audit Office (NAO), 220 of the 700 largest firms in the UK paid no UK corporation tax at all in 2005/06, the period immediately preceding the global economic crisis (Comptroller and Auditor General 2007). And this refers only to 'legal' tax avoidance; it does not include illegal tax evasion. Such widespread tax manipulation sits uncomfortably alongside the huge levels of public assistance received by private companies in corporate welfare each year (see Farnsworth 2012). Tax evasion and avoidance undermine government revenues and the public policies that depend on them, and threaten the legitimacy of the entire tax system. But despite a degree of acquiescence, and even complicity, by many governments in corporate tax avoidance, a combination of political and economic factors is forcing corporate taxation up the political agenda. Against a backdrop of campaigns by unions and nongovernmental organisations (NGOs; Americans for Tax Fairness undated; Canadians for Tax Fairness undated; UK Uncut undated), official investigations into the tax affairs of TNCs in the US and UK - including Apple, Microsoft, Hewlett-Packard, Google, Amazon, and Starbucks - have provided a rare glimpse of the tax strategies of TNCs, as well as their power to shape tax rules and how they are interpreted (House of Commons Committee of Public Accounts 2012, 2013a, 2013b; Permanent Subcommittee on Investigations 2012, 2013). These official 
investigations form part of a broader political narrative precipitated by the high public financial costs of the economic crisis and the current 'age of austerity'. By pulling together a wide range of pressing fiscal challenges, encompassing falling tax revenues, growing budget deficits, expanding public debt, the distribution of the tax burden between domestic and international capital, and corporate tax avoidance (Braunstein 2004; Center for American Progress undated; Garofalo 2012; Gravelle 2011; McIntyre et al. 2011; PricewaterhouseCoopers 2011; Schwartz 2013; Sullivan 2007; United States Government Accountability Office 2013), this narrative has enhanced the opportunities for, and demands upon, policy makers to act, not just in the UK, but internationally, culminating, in July 2013, with the Organisation for Economic Cooperation and Development's (OECD's) attempt to co-ordinate action by nation states to tackle corporate tax avoidance (Organisation for Economic Cooperation and Development 2013a).

The following discussion explores the tax practices which have given rise to this policy response and examines how contemporary trends in corporate tax planning, avoidance, and enforcement, undermine the capacity of modern tax systems to deliver effective public policies. The article draws on evidence given to the US Senate's Permanent Subcommittee on Investigation (PSI; Permanent Subcommittee on Investigations undated) into corporate tax avoidance (Permanent Subcommittee on Investigations 2012, 2013) and a similar official inquiry by the UK Parliament's Public Accounts Committee (PAC) (House of Commons Committee of Public Accounts 2012, 2013a, 2013b) and aims to situate TNCs' strategies to minimise tax within a broader discussion of corporate power, the state's ability to regulate TNCs, and the nature of corporate harm.

Throughout the article we use the term corporate tax avoidance, which, although commonly defined as efforts to minimise tax obligations that are contrary to the intentions of legislators (Murphy 2010), is riven with ambiguity. Although formally distinct from corporate tax evasion, which is illegal, the two overlap at the margins, separated ultimately by shifting, low visibility accounting practices, and their impact on government revenues is essentially the same. Moreover, as we argue below, there is increasing evidence to suggest that governments and tax authorities have intentionally sought to limit certain corporations' tax liabilities to levels well below statutory and effective rates, as part of a global competition for business investment that creates incentives for governments to either 'turn a blind eye' or deliberately create environments where companies can avoid paying tax without censure. In terms of the conceptualisation of tax avoidance, such collusion with corporations in avoiding tax requires a distinction to be made between tax law, as it is made by legislators, and tax policy, as it is implemented.

The article is divided into three sections. The first section sets contemporary corporation tax policy within its political and economic context by outlining the effects of increased capital mobility on corporate tax rates. The second section outlines some of the key methods that corporations use to minimise their tax liabilities, explores the interdependencies between the demand for reduced tax liabilities and the professional infrastructure of tax planning and avoidance, and examines how the contemporary political economy of corporate taxation enhances the bargaining power of TNCs in the implementation of tax policy. In the final section and conclusion we discuss the implications of contemporary trends in corporation tax policy and avoidance for public policy and the study of social harm. 


\section{Contextualising Corporate Tax Avoidance}

Corporate tax rates have been falling steadily since the 1960s across most OECD countries (Swank 2002). In the UK, the main rate of corporation tax was $52 \%$ in $1980,34 \%$ in $1990,30 \%$ in 2000, and $28 \%$ in 2010. In 2013 it was cut to $22 \%$ and it is due to be cut again to $20 \%$ by $2015 .{ }^{1}$ The drivers of this process have been a combination of corporate lobbying and structural pressures on successive governments eager to induce businesses to invest within their jurisdictions. Structural pressure arises from the fact that overall tax revenues, including taxes on general incomes and consumption, are ultimately raised on such investment and has its origins in the relaxation of capital and exchange controls and, in the case of European corporations, the intensification of economic integration in Europe, which has increased capital mobility. As a result, even companies that have fixed plant - and cannot easily relocate production elsewhere - have been able to shift their tax liabilities to jurisdictions with more favourable tax regimes. This has placed increasing pressure on governments to compete aggressively to both retain existing investment and attract new investment by reducing statutory rates of corporate taxation in a fiscally compromising game of beggar thy neighbour (Overesch and Rincke 2011). ${ }^{2}$ According to the US Congressional Research Service, the cut in the rate of US corporation tax from $48 \%$ to $35 \%$ between 1986 to 1988 by the Tax Reform Act of 1986 was instrumental in the latest phase of this process, triggering a wave of corporate tax cuts around the world and creating a situation in which 'none will gain capital, but all will lose revenue' (Gravelle 2014, p.18).

In the UK, the drivers and effects of tax competition are illustrated by various initiatives aimed at encouraging new indigenous and foreign direct investment. In 2001, for example, the then Labour government set out its stall, appealing directly to business leaders for new investment based on the tax and regulatory regime it had created:

We have created a tax framework which encourages investment and enterprise by reducing the rate of corporation tax, making capital gains tax more pro-enterprise, introducing incentives for R\&D and making permanent the capital allowances available to small firms. Taken overall, UK business taxation levels, including employers' social security contributions and corporation tax, are competitive with the rest of the European Union. This is a situation we intend to maintain. (The Labour Party 2001)

More recently, the coalition government's commitment to 'creating the most competitive corporate tax regime in the G20' (HM Treasury 2013) has coincided with, and is helping to exacerbate, a new fiscal crisis - with continuing falls in corporation tax revenues alongside an expanding deficit.

Tax competition has intensified as a result of a significant growth in Offshore Financial Centres (OFCs) which help facilitate the market for tax planning and set the context for weak systems of enforcement and government complicity in tax avoidance. OFCs are low-tax countries or jurisdictions that offer financial services to non-residents on a scale incommensurate with the size of their domestic economies (Palan, Murphy and Chavagneux 2010; Picciotto 1999). Non-residents pay little or no tax and there is little transparency either within the country or outside it (Monetary and Capital Markets Department and the Legal Department 
2008). In 2010, there were around 70 OFCs worldwide (Christensen and Murphy 2004; Farquet 2012; Monetary and Capital Markets Department and the Legal Department 2008; Smith 2013). According to research carried out by the United Nations Centre for Trade and Development, Foreign Direct Investment (FDI) flows to OFCs are at a historically high level, having risen rapidly since 2007 following the start of the financial crisis (United Nations Conference on Trade and Investment 2013). ${ }^{3}$ OFC economies now account for a non-negligible and increasing share of global FDI flows, at about 6\% (Monetary and Capital Markets Department and the Legal Department 2008; Murphy 2008). Added to this, an increasing number of non-OFC countries (such as Austria, Portugal, Hungary, Denmark, and the Netherlands) are beginning to behave like OFCs, through the use of Special Purpose Entities (SPEs) (United Nations Conference on Trade and Investment 2013). Hungary, Luxembourg and the Netherlands reported more than US\$600 billion in investment flows to SPEs for 2011 (United Nations Conference on Trade and Investment 2013), redirecting financial flows to third countries in order to avoid tax.

The use of OFCs by TNCs is significant. One survey estimated that $99 \%$ of European quoted companies have operations in tax havens (Tax Justice Network 2009), whilst a recent US study found that 82 of the top 100 publicly-traded US companies were operating subsidiaries in OFCs in 2012, helping them to avoid paying an estimated US $\$ 90$ billion in federal taxes each year (Smith 2013). OFCs provide TNCs with incentives (because of the low tax rates in tax havens) and opportunities (because of the secrecy provisions tax havens offer) to shift incomes. It is normal in OFCs for little or no tax to be charged on transactions so long as they have, or can be deemed to have, taken place elsewhere (Murphy 2008). ${ }^{4}$

A vast range of tax benefits - also used to induce corporate investment and other 'desirable' business activities (Klassen and Laplante 2012; Sahadi 2013) increase the opportunities for tax avoidance and help to expand the gap between statutory and effective tax rates (Citizens for Tax Justice 2013). An examination of OECD data reveals that the tax breaks offered to businesses in the late 2000s were annually worth around $1.5 \%$ of gross domestic product (GDP) in the UK and around $4.5 \%$ in the US (Organisation for Economic Cooperation and Development 2009). The schemes offered by governments can be hugely profitable. Companies can write off capital investment against tax and make use of 'accelerated depreciation' schemes which typically allow the company to write off their entire investment in the first few years, much more quickly than the actual time taken for the asset to wear out. Indeed, governments often incentivise companies to invest by allowing them to write off more than $100 \%$ of the costs of new investment (McIntyre and Gardner 2014). The scope of tax breaks also tends to be widely drawn. In the US, for example, the domestic productions activities deduction allows companies to deduct $9 \%$ of the cost of qualified manufacturing expenses from their income tax (Internal Revenue Service 2013). In practice, the deduction extends to processing and preparation of food products for sale at wholesale, which includes grinding coffee and making hamburgers (Karnis 2010), and although eligibility for the deduction is limited to manufacturing that occurs 'substantially' in the US, the threshold is set at $20 \%$. Thus, whilst governments compete on headline rates of corporate taxation, an elaborate system of tax breaks when combined with tax avoidance, results in tax rates that are far lower than statutory rates. Although estimates vary (Bartlett 2013; Citizens for Tax Justice 
2012), research by the US Government Accountability Office suggests that profitable US corporations paid an effective federal tax rate of $12.6 \%$ in $2010^{5}$ (United States Government Accountability Office 2013), compared with a statutory rate of $35 \% .^{6}$ In the UK, a TUC commissioned report found that the 700 largest corporations in the UK had an effective tax rate $7.5 \%$ lower than the statutory rate (30\% at the time) (Murphy 2008).

\section{Corporate Tax Avoidance and Enforcement}

Although the details of TNCs' efforts to reduce their tax liabilities can be quite complex, the underlying strategy is simple: TNCs design their businesses to locate as much income as possible in countries where taxes are low and as many costs as possible in jurisdictions where the statutory tax rate is high (Schjelderup et al. 2009). Although some techniques skilfully produce this effect by exploiting differences between tax residency rules, ${ }^{7}$ most stem from the system used to allocate profits to countries. TNCs produce separate accounts for each country in which they operate and set the prices associated with intragroup transactions that happen across tax borders, which provide a basis for determining where profits and costs are booked. This is important because multiple filings in multiple countries reduces transparency and prevents national tax authorities from being able to verify the accuracy of tax returns made by TNCs. But whilst a lack of cross-national co-operation between tax authorities makes existing tax agreements difficult to enforce (Directorate-General Taxation and Customs Union 2013), evidence given to the PAC suggests that the rules themselves are widely defined and open to interpretation, and, therefore, play a key role in facilitating avoidance. The OECD's guidance on transfer pricing, which involves one part of a company within lower-tax regimes securing and 'selling' goods at inflated prices to other parts of the company in higher-tax regimes, thus reducing profits and tax liabilities in the latter, clearly stipulates that profits should be taxed where genuine economic activity is carried out (Organisation for Economic Cooperation and Development 2010). However, what constitutes a genuine site of economic activity is often difficult to determine, especially where companies have managed to divorce the distribution and sale of goods from their production, which is tied to the 'brand' and/or intellectual property that resides in the product. The key here is that the 'economic activity' linked to the brand or intellectual property could be sited anywhere, far away from the sale of particular goods and services. In this way, Starbucks can claim that a great deal of the economic activity associated with the sale of its coffee stems from its R\&D activities in the US and its coffee processing enterprise in Switzerland, where it buys raw beans, and the Netherlands, where its roasting plant is located. Coffee purchases from the Netherlands are levied at a premium of $20 \%$, whilst revenue generated in British stores is subject to a $6 \%$ charge in royalty payments. ${ }^{8}$ Similarly, Google can claim that its product depends on its R\&D activities in California, whilst Amazon can claim that the technology, infrastructure and organisation residing in Luxembourg is what matters in the delivery of its products, rather than the warehouses in the UK that are argued to function primarily as distribution centres. However, as the PAC pointed out, the company employed 134 staff in Luxembourg, but 2,266 in the UK, and whilst it generated an estimated $£ 122.8$ million of profit in the UK in 2010, and just $£ 2.2$ million in Luxembourg, it located most of its tax liabilities in Luxembourg where the rates are lower (House of Commons Committee of Public 
Accounts 2012). By the time companies have allocated part of their turnover to pay royalties, or repay loans at inflated prices to their parent companies, not to mention written off various tax deductibles, there may be little or no profit left in a subsidiary on which to declare and pay corporation tax. Starbucks, for instance, has been able to report accounting losses in all but one of the 15 years in which it has traded in the UK.

Creativity in the interpretation of tax rules appears to be embedded in the institutional processes used to develop them. As the PAC pointed out, large accountancy firms second staff to the Treasury to provide advice on formulating tax legislation so that when they return to their firms, they have inside knowledge of how to identify loopholes in new legislation and advise their clients on how to take advantage of them (House of Commons Committee of Public Accounts 2013a). Other evidence indicates that firms' ability to interpret tax rules creatively reflects the imbalance of resources between accountancy firms and tax authorities. The returns involved in avoiding tax are considerable. Sikka (2012) cites one example involving the US telecommunications company WorldCom, which involved a return of between $1,000 \%$ and $3,800 \%$ on capital invested in a scheme organised by KPMG. According to a 2003 PSI report, returns such as these have led TNCs to invest 'substantial resources' on 'forming alliances, and developing the internal and external infrastructure necessary to design, market, and implement hundreds of complex tax shelters' (US Senate Permanent Subcommittee on Investigations 2003, p.18). In 2009, the four major accountancy firms alone employed nearly 9,000 people and earned $£ 2$ billion in the UK and as much as US $\$ 25$ billion globally from their tax work; an estimated $50 \%$ of their fees now come from 'commercial tax planning' and 'artificial avoidance schemes' (Tax Gap Reporting Team 2009a). The substantial imbalance of resources between the private tax avoidance industry and tax authorities caused by this rapid development in professional expertise (Sikka 2003) was highlighted by the PAC which reported that there are now around four times as many staff working for the accountancy firms on transfer pricing alone as there are staff working for the UK tax authority, Her Majesty's Revenue and Customs (HMRC; House of Commons Committee of Public Accounts 2013a, p.3). According to Everson (2011), the Commissioner of the US Inland Revenue Service between 2003 and 2007, this creates the professional space for creativity to thrive as tax professionals are encouraged to ignore disclosure rules in the knowledge that tax authorities are unlikely to discover the underlying transactions, particularly where penalties can readily be absorbed as an operating cost. The outcome, according to the House of Commons Committee of Public Accounts (2013b) is that:

HM Revenue \& Customs (HMRC) appears to be fighting a battle it cannot win in tackling tax avoidance. Companies can devote considerable resource to ensure that they minimise their tax liability. There is a large market for advising companies on how to take advantage of international tax law, and on the tax implications of different global structures. (p.3)

In addition, resource disparities constitute an important driver of co-operative enforcement practices which create an enabling context for both creativity in tax accounting and avoidance. Even where companies are accused of having paid less tax than HMRC think is legally due, the outcome is more likely to be a negotiated settlement than legal action. Tax policy, in this context, is reduced to a negotiation 
between the company and the state characterised by marked inequalities in bargaining power that derive from contrasting resource capabilities, organisational pressures, and objectives. In contrast to companies which can make substantial gains from challenging tax authorities' interpretation of their liabilities, tax authorities must not only work within limited budgets, but also be sensitive to government policy in using tax regimes to create a pro-business environment. This is built into the criteria used to determine whether the value of settlements are reasonable, which includes a consideration of "whether the settlement was as good as, or better than, the outcome that might be expected from litigation, considering the risks, uncertainties, costs and timescale of litigation' (Comptroller and Auditor General 2012, footnote 134). A legal challenge brought against HMRC into the circumstances leading to one of these settlements with the US investment bank Goldman Sachs, provides a rare insight into the extra-legal levers which TNCs can use to exploit this process. Goldman Sachs was accused of privately negotiating a reduction of $£ 10$ million on a total interest payment bill of $£ 40$ million. The interest charges were due on its outstanding tax liabilities which arose because the company was found to have engaged in illegal tax avoidance practices in the 1990s. In negotiations over its tax liabilities with HMRC, Goldman Sachs 'threatened to withdraw' from a banking code of practice which would, according to the Permanent Secretary for Tax at HMRC at the time, have been highly embarrassing for the Chancellor of the Exchequer and HMRC. A further problem is that such cases are conducted in private. The former Head of HMRC in particular was criticised as having 'an unduly cosy relationship with large companies it is trying to settle tax disputes with' and of having 'had a significant number of lunches and dinners with companies, tax lawyers and tax advisers - as many as 107 such engagements in two years' (House of Commons Committee of Public Accounts 2012, p.16).

The weaknesses inherent in co-operative approaches to collecting corporate tax are also illustrated by the so-called Disclosure of Tax Avoidance Schemes (DOTAS). Under DOTAS, companies engaging in tax avoidance disclose their avoidance activities to HMRC who, in turn, rule on their legality. If legal, the tax avoidance scheme can be utilised for financial gain until such a time as HMRC acts to close the loophole that facilitated it. At that point, companies will move on to the next scheme. The net effect is a permissive environment for accounting innovation, which stretches tax practices and rules to their limits (Hanlon 1994; Sikka 2008, 2012). Although some schemes have subsequently been closed down since the introduction of DOTAS, the UK NAO stated that it has had little impact on the use of aggressive schemes, largely because HMRC lacks the necessary resources to take effective pre-emptive measures (National Audit Office 2012). A recent NAO report on DOTAS estimated the total 'risk' (or cost in lost revenues) associated with the 41,000 open cases in March 2012, to be in the region of $£ 35$ billion (although some of this amount is associated with individuals rather than corporations) (Comptroller and Auditor General 2012).

Arguably, the key significance of the relative under-resourcing of HMRC is that it illustrates the relatively low political priority given to collecting tax revenue from corporations. In 2012, HMRC reported that it had 1,200 staff overseeing 783 large businesses, in respect of which $£ 25$ billion in tax was potentially outstanding; this contrasted with 2,876 staff at the Department of Work and Pensions examining allegations of fraud worth $£ 1.2$ billion against benefit claimants (House of Commons Committee of Public Accounts 2012; Syal 2012). 
Moreover, it is important to understand that it is not just companies that governments are doing battle with over taxation, it is also other states. The US PSI investigation into the tax affairs of Apple, for instance, found that, for many years, Ireland has provided Apple affiliates with a special tax rate substantially below its already low statutory rate of $12 \%$. Apple told the subcommittee that it had obtained this special rate through negotiations with the Irish government. Answering questions on the alleged deal with Apple at a European Union (EU) summit on banking secrecy, Irish Prime Minister, Enda Kenny, denied the existence of 'special' deals with key corporations and claimed that the Irish government would continue to compete for international business using a 'transparent' tax regime (Anon 2013a). According to Apple, this special corporate income tax rate had been 2\% or less since 2003 (Permanent Subcommittee on Investigations 2013). Starbucks has also apparently reached a similar 'secret' deal with the Netherlands. When asked by the chair of the PAC for details of the tax rate paid by Starbucks in the Netherlands, the company's representative replied:

I am very happy to provide that to the Committee, but I am bound by confidentially to the Dutch Government on that. . . The tax authority, under our Dutch ruling, has asked us not to share that publicly. (House of Commons Committee of Public Accounts 2012, response to Question 246)

Such evidence of bespoke tax deals reached between corporations and governments throws into question the very sustainability of the corporate tax system and raises serious questions about the alignment of government and corporate interests and its effects on tax revenues and public spending in future. It also raises questions about what lengths governments will have to go to in future to entice companies to invest and suggests that international agreement on corporate tax competition may be further away than is presently thought. There is growing evidence that differences in statutory rates within the EU has led to a substantial redistribution of corporate tax revenues from relatively high to relatively low corporate tax regimes (Huizinga and Laeven 2008).

\section{Social and Economic Costs of Corporate Tax Abuse}

The following section outlines the major social and economic costs associated with tax abuse, beginning with tax avoidance.

There is a dearth of accurate and consistent data on the costs of avoidance.

Low standards of transparency in corporate financial reporting, differences in what should be included in estimates, and disagreements over the meaning of tax avoidance have produced varying estimates (Miller 2013). The UK government estimates that the corporation tax gap - the difference between the amount of tax expected and the actual amount paid - amounted to £4.1 billion in 2010/11 (the most recent estimation year available) (HM Revenue and Customs 2012, Table 1.3, Qq 13-15). A highly-regarded tax justice advocate in the UK, Richard Murphy, suggests that a more accurate estimate for the corporate tax gap is around $£ 12$ billion (Murphy 2008, 2012). When we consider the significant tax gaps that apply to individual companies, a figure closer to Murphy's does not look unreasonable. In 2012, for instance, Amazon earned $£ 6$ billion in sales in the UK, 
yet paid only $£ 517,000$ in corporation tax, whilst in 2013 , Google paid $£ 11.6$ million in UK corporation tax on UK revenues of $£ 3.4$ billion: $£ 770$ million less than it would have paid if it had paid tax at the full rate of $23 \%$ in 2013 (Rankin, O'Carroll and Monaghan 2013). Aggregate measures for the sums involved in different forms of avoidance also provide intuitive support for Murphy's higher figure. One widely-cited estimate of the misuse of transfer pricing suggests that, in 2004 , between $45 \%$ and $60 \%$ of all international transactions related to the sale of goods and services involved manipulated prices, at a cost of US\$365 billion (Baker 2005). Inaccurate pricing in these transactions was calculated to account for $10-11 \%$ of their value, indicating that that transfer pricing alone accounted for 5-7\% of world trade (Baker 2005).

The social impact of such large losses to government revenues is highly significant, especially during times of fiscal crisis. Avoidance, coupled with policy measures that countenance only reductions in corporation tax, redistributes the tax burden elsewhere, including onto lower income citizens. It also undermines the sustainability of public policies, including the kinds of infrastructure projects and investment in education, health care and pensions that are essential either to satisfy corporate needs or reduce corporate harms of various kinds (for a discussion of harm see Hillyard et al. (2004); Hillyard and Tombs (2007)). This makes for a tense and contradictory policy environment, where public policies, including tax policies, operate in the interests of corporations that, in turn, utilise every mechanism to reduce their tax burden. As the chief executive officer of Google put it, after coming under heavy criticism for its own tax avoidance strategies:

I am very proud of the structure that we set up. We did it based on the incentives that the governments offered us to operate . . . It's called capitalism. We are proudly capitalistic. I'm not confused about this. (Kumar and Wright 2012)

In addition, the infrastructure of avoidance helps to produce economic instability. OFCs and the global flow of unregulated capital was a major cause of the post2007 economic crisis. Tax havens helped fuel the volume of international capital flows and the search for high-risk returns which were not only instrumental in creating the 2007 crisis in the first place, but also helped to spread contagion around the globe. They also encouraged companies, including banks, to divert their own capital to tax havens, with the result that they became excessively leveraged, with huge and unsustainable levels of debt and to conceal their losses (Shaxson 2010).

Third, aggressive tax competition undertaken by governments risks creating imbalances in the economy. Relatively high concentrations of highly-mobile capital within countries increases the pressure on those countries to continue to compete effectively to retain companies that have few physical and even fewer 'emotional' ties to a country. As already discussed above, all governments face real tensions in trying to police and clamp down on tax avoidance, whatever their ideological and political leanings. Recent UK policy, under both Labour and the Conservatives, has been driven more by a desire to placate businesses and induce higher rates of investment in an increasingly competitive global environment. Because of this, governments have been slow to move. The post-1997 Labour government promised a clampdown as soon as it came to power. Plans drafted in 1997 for a 'general anti-avoidance rule' (GAAR) were eventually shelved in 
favour of a review into the issues. The 'Hartnett review', established in 2001, sought to redefine the relationship between government and business as one of 'mutual trust' on the matter of taxation and other regulations. The Labour Party was keen to prove that it, rather than the Conservatives, was the natural ally of business. The Hartnett review promised 'a new, faster process' for dealing with corporate tax disputes which would focus 'only on the most important issues' and would foster a 'collaborative approach'. The new approach was cemented through a new large corporate forum and a business tax forum (Tax Gap Reporting Team $2009 b$ ). This strategy, like the coalition government's after it, was born, in part, out of the realisation that existing mechanisms for raising corporation tax and enforcing tax law were failing.

Fourth, studies suggesting that the major TNCs report significantly lower taxable income compared with domestic-controlled corporations illustrate the competitive advantages that TNCs gain over nationally based companies, by shifting profits to low-tax jurisdictions and by having access to the largest funds necessary to make use of the most lucrative tax avoidance schemes (Collins, Kemsley and Shackelford 1997). The impact on their (national) competitors, and ultimately consumers, can be huge, placing TNCs in a better position to compete for new markets or take over competitors in higher-tax countries (Anon 2013b; Desai and Hines 2004), and, over a relatively short period of time, lead to market dominance.

Fifth, there is a risk that systematic tax avoidance by one group delegitimises the whole tax system. Coupled with this is growing disquiet amongst domestic companies that find it more difficult to take advantage of international methods of tax avoidance. The result is falling revenues generally, which further undermines public services. Lastly, but probably most importantly, corporate tax avoidance, and tax competition, undermine state revenues and public policies. This is especially true at this time of austerity amid draconian cuts to social welfare expenditure that are having their greatest impact on the poor. Making up the gap between public revenues and expenditure by shifting taxes onto immobile capital or citizens may only make matters worse. And the current tax debate, in part shaped by private business interests, is intolerant of income taxes, with the consequence that the most regressive forms of taxation which impact most heavily on lower incomes, namely consumption taxes, are the ones that are most likely to be used to fill any gaps in revenues.

\section{Conclusions}

Corporate tax abuse is a growing problem with wide-ranging social and economic costs, especially in the context of the recent global financial crisis. Transnational corporations employ increasingly sophisticated methods that are designed to reduce their tax bill. Some do so through the adoption of illegal tax evasion methods. But others do so through the employment of relatively innocuoussounding methods of 'tax efficiency'. Together, both methods bring huge costs in terms of lost tax revenues. But it is the latter that is especially problematic, precisely because it is interpreted by many TNCs as simply part of the modern way of doing business.

There is nothing surprising about the fact that corporations should seek to minimise their tax bill. What is more surprising and worrying is the extent of the 
problem and the fact that governments also appear to be colluding in the practice. The battle ground is no longer between corporations and governments, but between governments and governments, each one keen to attract new private sector investment with increasingly attractive inducements to companies to facilitate such investment. TNCs, in the context of relatively permissive national tax environments may be excused for thinking that such permissiveness is simply part of the overall package of inducements. Certainly, the evidence provided in this article suggests that such collusion on the part of governments in tax avoidance is par for the course.

Although the direction of political debate may be shifting, it is by no means clear that governments are any closer to being able to tackle corporate tax abuse. On the other hand, the fact that official inquiries have been carried out into the tax affairs of some of the largest and most powerful transnational corporations, and that these companies have been heavily condemned by elected officials and the mainstream media, is a positive, but unusual, step in the right direction. The OECD is also seeking to put in place tighter international frameworks that would make it harder for companies to dodge tax, although the details have yet to be ironed out. The costs of the financial crisis, a significant part of which was associated with bailing out private banks, has encouraged some within politics to question the continued legitimacy of systematic tax avoidance. The kind of complex financial arrangements which help companies to avoid tax, to some extent mirror the kind of practices which led to the post-2007/08 financial crash in the first place and, for governments staring at increasingly large fiscal holes, there is less willingness to allow business to continue as usual. The result of this has been high-profile inquiries into corporate taxation in the UK and the US, followed by more concerted efforts at the international level to co-ordinate action to tackle tax abuse. The UK and US investigations alone have had far-reaching consequences in that they have provided rare glimpses into the otherwise highlysecretive world of corporate tax planning practices. What is immediately clear from the evidence provided to the official inquiries carried out in the UK and US is that tax abuse is far more sophisticated, and has far greater potential negative implications for public policies than the social science literature has, perhaps, given credit for. Corporations have proven themselves to be more mobile (at least when it comes to declaring profits), more capable (in terms of protecting their own narrow corporate interests), less responsible (at least in terms of ignoring the consequences of their actions), and more duplicitous (in demanding more from the state at the same time that they appear to be less willing to pay for the state) than many would have imagined.

The net result of this is that, for those opposed to corporate tax abuse, there are currently reasons to be both optimistic and pessimistic. The moves at the international level to tackle tax abuse, coupled with growing disquiet within mainstream political debate concerning systematic tax avoidance, on the back of the financial crisis, may lead to measures that will more effectively tackle the problem. At the same time, however, the UK government has opposed such moves on the basis that they may undermine the strength of the City of London. Unless there is concerted international governmental reform to tackle corporate tax abuse, it is clear that the problem of corporate tax avoidance will likely intensify and become more harmful over time. 


\section{Notes}

1 For recent trends in other jurisdictions, see Organisation for Economic Cooperation and Development (2013b).

2 One recent study estimated that, in the absence of tax competition, the mean statutory tax rate of Western European countries in 2006 would have been about 12.5 percentage points above its actual level (Overesch and Rincke 2011).

3 The average annual FDI inflows to OFCs in the period 2007 to 2012 were US\$75 billion, well above the US $\$ 15$ billion average of the pre-2007 period (2000 to 2006) (United Nations Conference on Trade and Investment 2013).

4 One analysis of financial and ownership data of more than 1,500 TNCs operating in India found that in 2010, TNCs with links to OFCs reported $1.5 \%$ less profits. They paid $17.4 \%$ less in taxes per unit of asset and $30.3 \%$ less in taxes per unit of profit than TNCs with no such links (Janský and Prats 2013).

5 The figure relates to profitable US corporations that filed a Schedule M-3 and represents the percentage of tax paid on pre-tax worldwide income reported in their financial statements (for those entities included in their tax returns). When foreign and state and local income taxes are included, the figure increases to around 17\% (United States Government Accountability Office 2013).

6 The federal rate on the largest US corporations is $35 \%$. State and local governments may also impose income taxes. Corporations are permitted to deduct state and local income taxes when calculating their federal taxable income, generally resulting in a net rate of approximately $40 \%$ (KPMG undated).

7 For example, Apple has been able to minimise most of its tax liabilities on offshore earnings of US $\$ 102$ billion by structuring three Irish subsidiaries to be tax residents of neither the US - where they are managed and controlled - nor Ireland - where they are incorporated. Ireland uses a management and control test to determine tax residency, while the US determines tax residency based upon a company's place of formation. In its evidence to the PSI, Apple explained that although one of its subsidiaries, AOI, was incorporated in Ireland, it was not tax resident there because it was neither managed nor controlled in Ireland. It also maintained that, because AOI was not incorporated in the US, it was not a US tax resident under US law either (Permanent Subcommittee on Investigations 2013).

8 Starbucks was also found to use several accounting methods to limit its tax liabilities to just $£ 8.6$ million on $£ 3.1$ billion in sales over a 13 -year period. Amongst other things it was found to utilise inter-company loans, imposing relatively high levels of interest, which effectively diverts what would otherwise be profit into debt repayments to the holding company. Starbucks UK paid group companies $£ 2$ million in interest in 2011.

Starbucks typically charges its subsidiaries $4 \%$ above the Libor (London Interbank Offered Rate) in interest. As a comparison, KFC charges its subsidiaries around the Libor plus $2 \%$, whilst the UK units of McDonald's pay affiliates interest at or below the Libor (Bergin 2012).

\section{References}

Americans for Tax Fairness (undated) Available at: http://www.americansfortaxfairness.org/ (accessed 24 January 2014). Anon (2013a) 'EU summit ends banking secrecy', The Japan Times News. Available at: http://www.japantimes.co.jp/news/2013/05/24/ (accessed 22 August 2013).

Anon (2013b) Tax Avoidance: The Hidden Cost, BBC. Available at: http://www.bbc.co.uk/programmes/b01s0df4 (accessed 27 August 2013).

Baker, R.W. (2005) Capitalism's Achilles Heel, Hoboken, NJ.: John Wiley. 
Bartlett, B. (2013) New York Times: Effective Corporate Tax Rates. Available at: http://ctj.org/ctjinthenews/2013/11/new_york_times_effective_corporate_tax_rate. php (accessed 22 February 2014).

Bergin, T. (2012) Special Report: How Starbucks Avoids UK Taxes, Reuters. Available at: http://uk.reuters.com/article/2012/10/15/us-britain-starbucks-taxidUKBRE89E0EX20121015 (accessed 23 August 2013).

Braunstein, E. (2004) Declining Corporate Income Taxes in the 1990s: A Stateby-State Analysis of Effective Tax Rates, Amherst, MA.: University of Massachusetts.

Canadians for Tax Fairness (undated) Available at: http://www.taxfairness.ca/page/about-us (accessed 24 January 2014).

Center for American Progress (undated) 10 Graphs that Prove the United States is a Low-Tax Country. Available at: http://www.americanprogress.org/issues/2011/ 06/pdf/low_tax_graphs.pdf(accessed 18 August 2013).

Christensen, J. and Murphy, R. (2004) 'The social irresponsibility of corporate tax avoidance: taking CSR to the bottom line', Development, 47(3), 37-44.

Citizens for Tax Justice (2012) The U.S. Has a Low Corporate Tax, Washington, DC.: Citizens for Tax Justice.

Citizens for Tax Justice (2013) Ten (of Many) Reasons Why We Need Corporate Tax Reform: Companies from Various Sectors Use Legal Tax Dodges to Avoid Taxes, Washington, DC.: Citizens for Tax Justice.

Collins, J., Kemsley, D. and Shackelford, D. (1997) 'Transfer pricing and the persistent zero taxable income of FCCs', Journal of the American Taxation Association, 19(Supplement), 68-83.

Comptroller and Auditor General (2007) Management of Large Business Corporation Tax, London: The Stationery Office.

Comptroller and Auditor General (2012) Settling Large Tax Disputes (National Audit Office), London: The Stationery Office. Available at: http://www.publications.parliament.uk/pa/ld201314/ldselect/ldeconaf/48/4808.hm (accessed 3 October 2014).

Desai, M.A. and Hines, J.R. (2004) 'Old rules and new realities: corporate tax policy in a global setting', National Tax Journal, 57(4), 937-60.

Directorate-General Taxation and Customs Union (2013) Draft Discussion Paper on the 'Tax Havens' Recommendation (European Commission, Platform for Tax Good Governance), Brussels, Belgium: European Commission.

Everson, M.W. (2011) 'Lawyers and accountants once put integrity first', New York Times. Available at: http://www.nytimes.com/2011/06/19/opinion/19everson. html?pagewanted $=$ all (accessed 30 August 2013).

Farnsworth, K. (2012) Social Versus Corporate Welfare: Competing Needs and Interests within the Welfare State, Basingstoke: Palgrave Macmillan.

Farquet, C. (2012) The Rise of the Swiss Tax Haven in the Interwar Period: An International Comparison (EHES Working Papers in Economic History No. 27), Lausanne, Switzerland: University of Lausanne, European Historical Economics Society.

Garofalo, P. (2012) U.S. Corporate Tax Rate Plunges to 40 Year Low of 12.1 Percent. Available at: http://thinkprogress.org/economy/2012/02/03/418171/corp ate-taxes-40-yearlow/(accessed 20 August 2013).

Gravelle, J.G. (2011) International Corporate Tax Rate Comparisons and Policy Implications, Washington, DC.: Congressional Research Service. 
Gravelle, J.G. (2014) International Corporate Tax Rate Comparisons and Policy Implications, Washington, DC.: Congressional Research Service.

Hanlon, G. (1994) The Commercialisation of Accountancy: Flexible Accumulation and the Transformation of the Service Class, London: Macmillan.

Hillyard, P., Pantazis, C., Tombs, S. and Gordon, D. (Eds.) (2004) Beyond Criminology: Taking Harm Seriously, London: Pluto Press.

Hillyard, P. and Tombs, S. (2007) 'From “crime" to social harm?', Crime, Law and Social Change, 48(1-2), 9-25.

HM Revenue and Customs (2012) Measuring Tax Gaps 2012: Tax Gap Estimates for 2010-11, London: HM Revenue and Customs. Available at: https://www.gov.uk/government/uploads/system/uploads/attachment_data/file/249 146/mtg-2012.pdf (accessed 3 October 2014).

HM Treasury (2013) A Guide to UK Taxation, London: UK Trade and Investment.

House of Commons Committee of Public Accounts (2012) HM Revenue \& Customs: Annual Report and Accounts 2011-12, London: House of Commons.

House of Commons Committee of Public Accounts (2013a) Continuing Weakness of HMRC in its Efforts to Deal with Tax Avoidance. Available at: http://www.parliament.uk/business/committees/committees-a-z/commons-select/

Public -accounts-committee/news/tax-avoidance-therole-of-large-accountancyfirms/ (accessed 2 March 2014).

House of Commons Committee of Public Accounts (2013b) Tax Avoidance: The Role of Large Accountancy Firms, London: House of Commons.

Huizinga, H. and Laeven, L. (2008) 'International profit shifting within multinationals: a multi-country perspective', Journal of Public Economics, 92(56), 1164-82.

Internal Revenue Service (2013) Instructions for Form 8903, Washington, DC.: Department of the Treasury, Internal Revenue Service.

Janský, P. and Prats, A. (2013) Multinational Corporations and the Profit-Shifting Lure of Tax

Havens (Christian Aid Occasional Paper), London: Christian Aid.

Karnis, D. (2010) 'Maximizing the Section 199 deduction', Journal of Accountancy, September. Available at: http://www.journalofaccountancy.com/ Issues/2010/Sep/20102727.htm (accessed 28 February 2014).

Klassen, K.J. and Laplante, S.K. (2012) 'Are U.S. multinational corporations becoming more aggressive income shifters?', Journal of Accounting Research, 50(5), 1245-85.

KPMG (undated) Corporate Tax Rates Table. Available at: http://www.kpmg.com/global/en/services/tax/tax-tools-and-resources/pages/ corporate-tax-rates-table.aspx (accessed 2 March 2014).

Kumar, N. and Wright, O. (2012) 'Google boss: I'm very proud of our tax avoidance scheme', Independent. Available at: http://www.independent.co.uk Inews/uk/home-news/google-boss-im-very-proud-of-our-tax-avoidance-scheme8411974.html (accessed 22 February 2014).

McIntyre, R.S. and Gardner, M. (2014) The Sorry State of Corporate Taxes What Fortune 500 Firms Pay (or Don't Pay) in the USA And What they Pay Abroad 2008 to 2012, Washington, DC.: Citizens for Tax Justice.

McIntyre, R.S., Gardner, M., Wilkins, R.J. and Phillips, R. (2011) Corporate Taxpayers and Corporate Tax Dodgers 2008-10, Washington DC.: Citizens for Tax Justice and The Institute on Taxation and Economic Policy. 
Miller, H. (2013) 'Corporate tax, revenues and avoidance', in: C. Emmerson, P. Johnson and H. Miller (Ed.), The IFS Green Budget, London: Institute of Fiscal Studies.

Monetary and Capital Markets Department and the Legal Department (2008) Offshore Financial Centers: A Report on the Assessment Program and Proposal for Integration with the Financial Sector Assessment Program, Washington, DC.: International Monetary Fund.

Murphy, R. (2008) The Missing Billions: The UK Tax Gap, London: Trades Union Congress.

Murphy, R. (2010) Tax Avoidance, Evasion, Compliance and Planning, London: Tax Research UK.

Murphy, R. (2012) Why HMRC's Tax Gap Still Makes No Sense. Available at: http://www.taxresearch.org.uk/Blog/2012/10/18/why-hmrcs-tax-gap-still-makesno-sense/ (accessed 21 August 2012).

National Audit Office (2012) Tax Avoidance: Tackling Marketed Avoidance Schemes: Report by the Comptroller and Auditor General. HC 730. Session 2012-13. 21 November, London: National Audit Office, HMSO.

Organisation for Economic Cooperation and Development (2009) Tax Expenditures in OECD Countries, Paris, France: Organisation for Economic Cooperation and Development.

Organisation for Economic Cooperation and Development (2010) Transfer Pricing Guidelines for Multinational Enterprises and Tax Administrations Paris, Paris, France: Organisation for Economic Cooperation and Development.

Organisation for Economic Cooperation and Development (2013a) Action Plan on Base Erosion and Profit Shifting, Paris, France: Organisation for Economic Cooperation and Development.

Organisation for Economic Cooperation and Development (2013b) Basic (Nontargeted) Corporate Income Tax Rates, Paris, France: Organisation for Economic Cooperation and Development. Available at: http://www.oecd.org/tax/taxpolicy/Table\%20II.1_May\%202013.xlsx (accessed 2 February 2013).

Overesch, M. and Rincke, J. (2011) 'What drives corporate tax rates down? A reassessment of globalization, tax competition, and dynamic adjustment to shocks', Scandinavian Journal of Economics, 113(3), 579-602.

Palan, R., Murphy, R. and Chavagneux, C. (2010) Tax Havens: How Globalization Really Works, London: Cornell University Press.

Permanent Subcommittee on Investigations (2012) Offshore Profit Shifting and the U.S. Tax Code - Part 1 (Microsoft \& Hewlett-Packard), Washington, DC.: United States Senate.

Permanent Subcommittee on Investigations (2013) Offshore Profit Shifting and the U.S. Tax Code - Part 2 (Apple Inc.), Washington, DC.: United States Senate.

Permanent Subcommittee on Investigations (undated) About The Permanent Subcommittee on Investigations: Historical Background. Available at: http://www.hsgac.senate.gov/download/?id=95277f6f-e3c7-4adf-b106-

$70 c e 060134 c 5$ (accessed 20 February 2014).

Picciotto, S. (1999) 'Offshore: the state as legal fiction', in: M.P. Hampton and P.A. Jason (Eds.), Offshore Finance Centers and Tax Havens: The Rise of Global Capital, West Lafayette, IN.: Purdue University Press.

PricewaterhouseCoopers (2011) Global Effective Tax Rates. Available at: http:// businessroundtable.org/sites/default/files/Effective_Tax_Rate_Study.pdf (accessed 6 October 2014). 
Rankin, J., O’Carroll, L. and Monaghan, A. (2013) 'Google paid £11.6m in UK corporation tax last year', Guardian. Available at: http://www.theguardian.com/technology/2013/sep/30/google-paid-ukcorporation-tax (accessed 1 April 2014).

Sahadi, J. (2013) The 'Chicken Poop' Credit and Other Bad Tax Breaks, New York: CNN Money. Available at: http://money.cnn.com/2013/05/24/news/ economy/corporate-tax-breaks/index.html?iid=EL (accessed 23 August 2013). Schjelderup, G., Cappelen, A., Pedersen, J.G., Eriksen, M., Stenhammer, A.F., Lindbäck, L., Fjeldstad, O.-H., Joly, E., Gerhardsen, M. and Torvik, R. (2009) Tax Havens and Development (Ministry of Foreign Affairs, Official Norwegian Reports), Oslo, Norway: Government Administration Services Information Management.

Schwartz, N.D. (2013) 'Big companies paid a fraction of corporate tax rate', New York Times. Available at: http://www.nytimes.com/2013/07/02/business/bigcompanies-paid-afraction-of-corporate-tax-rate.html (accessed 23 August 2013).

Shaxson, N. (2010) Treasure Islands: Tax Havens and the Men who Stole the World, London: Bodley Head.

Sikka, P. (2003) 'The role of offshore financial centres in globalization', Accounting Forum, 27(4), 365-99.

Sikka, P. (2008) 'Enterprise culture and accountancy firms: new masters of the universe', Accounting, Auditing and Accountability Journal, 21(2), 268-95.

Sikka, P. (2012) 'The tax avoidance industry', Radical Statistics, 107, 15-30.

Smith, D. (2013) Offshore Shell Games: The Use of Offshore Tax Havens by the Top 100 Publicly Traded Companies, Boston, MA.: US PIRG.

Sullivan, M.A. (2007) The Effective Corporate Tax Rate Is Falling. Available at: http://www.taxanalysts.com/www/features.nsf/Articles/9B96723BDBA236078525

744B0060BAFA (accessed 18 August 2013).

Swank, D. (2002) Global Capital, Political Institutions, and Policy Change in Developed Welfare States, New York: Cambridge University Press.

Syal, R. (2012) 'Fewer DWP staff to investigate fraud claims against welfare contractors', Guardian. Available at: http://www.theguardian.com/politics/2012/ mar/30/fewer-investigators-fraud-claims-welfare (accessed 30 March 2012).

Tax Gap Reporting Team (2009a) 'Gilt-edged profits for profession's "big four", Guardian. Available at: http://www.theguardian.com/business/2009/feb/07/taxgap-avoidanceschemes (accessed 31 August 2013).

Tax Gap Reporting Team (2009b) 'The top gamekeeper', Guardian. Available at: http://www.theguardian.com/business/2009/feb/06/tax-gap-gamekeeper-inlandrevenue (accessed 28 February 2014).

Tax Justice Network (2009) Where on Earth Are You? Major Corporations and Tax Havens, London: Tax Justice Network.

The Labour Party (2001) The Best Place to do Business: The Labour Party's Business Manifesto, London: The Labour Party.

UK Uncut (undated) Available at: http://www.ukuncut.org.uk/about/ukuncut (accessed 24 January 2014).

United Nations Conference on Trade and Investment (2013) World Investment Report 2013: Global Value Chains: Investment and Trade for Development, New York and Geneva, Switzerland: United Nations.

United States Government Accountability Office (2013) Corporate Income Tax: Effective Tax Rates Can Differ Significantly from the Statutory Rate, Washington, DC.: United States Government Accountability Office. 
US Senate Permanent Subcommittee on Investigations (2003) The Tax Shelter Industry: The Role of Accountants, Lawyers and Financial Professionals, Washington, DC.: US Government Printing Office. 